\title{
A BÜKKFATAPLÓ [FOMES FOMENTARIUS (L. EX. FR.) KICKX.] BOGÁRFAUNISZTIKAI VIZSGÁLATA MAGYARORSZÁGON
}

\author{
Andrési Réka ${ }^{1}$, Janik Gergely ${ }^{2}$, Fürjes-Mikó Ágnes ${ }^{3}$, Eötvös Csaba Béla ${ }^{3}$ és Tuba Katalin ${ }^{1}$ \\ ${ }^{1}$ Soproni Egyetem, Erdőmérnöki Kar \\ ${ }^{2}$ KEFAG Zrt. \\ ${ }^{3}$ NAIK ERTI, Erdővédelmi Osztály
}

\begin{abstract}
Kivonat
Magyarországon a taplógombák bogárközössége kevéssé ismert, annak ellenére, hogy fajgazdag, specialista együttesek kötődnek hozzájuk. Vizsgálataink során 2010 és 2013 között az ország 27 településének környékéröl gyüjtöttünk be 193 termőtestet. A vizsgálattal a Fomes fomentarius (L. ex. Fr.) Kickx. magyarországi bogárközösségének feltárása, megismerése volt a célunk. A gyüjtés során a termőtestekből összesen 4726 bogáregyedet neveltük ki, amelyből 4703 egyedet sikerült faj szinten meghatározni. Összesen 27 faj jelenlétét tudtuk kimutatni. Egy részük tipikusan a bükkfataplóhoz kötődik (pl.: Bolitophagus reticulatus), de találtunk ragadozó életmódú fajt is (pl.: Bitoma crenata). A legnagyobb egyedszámban a Ciidae családba tartozó Rhopalodontus perforatust neveltük ki, amelyet a B. reticulatus és a Cis castaneus követett. A holtfák visszahagyása napjainkban egyre nagyobb jelentőséggel bír, így az ezeket lebontó taplógombák, valamint a hozzájuk kapcsolódó rovarközösségek vizsgálata az erdei ökoszisztémák alaposabb megismerése szempontjából elengedhetetlen.

Kulcsszavak: Fomes fomentarius, bükkfatapló, holtfa, bogárközösségek, mikofág bogarak, Bolitophagus reticulatus, Bitoma crenata
\end{abstract}

\section{FAUNISTICAL STUDIES ON COLEOPTERA OF TINDER CONK [FOMES FOMENTARIUS (L. EX. FR.) KICKX.)] IN HUNGARY}

\begin{abstract}
Our present knowledge on beetle communities of tinder fungi is far from complete in Hungary. During our research (20102013) 193 fruiting bodies of Fomes fomentarius (L. ex. Fr.) Kickx. were collected from vicinity of 27 Hungarian settlements. Our purpose was to gain new knowledge from the beetle communities related to Fomes fomentarius fruiting bodies in Hungary. A total of 4,726 beetles were reared out from the samples. 4,703 specimen of this, belonging to 27 species were identified for species level. Some beetle species typically associated with Fomes fomentarius (e.g. Bolitophagus reticulatus), but Bitoma crenata is a predator, so other species could attract it to the fruiting bodies. The largest individual was the Rhopalodontus perforatus, from the Ciidae family, followed by B. reticulaus and Cis castaneus. Nowadays, treating dead wood has an ever-increasing significance in forests, so the examination of decomposer fungi and their communities is necessary to get better knowledge from diversity and functions of the forest ecosystems.
\end{abstract}

Keywords: Fomes fomentarius, tinder fungi, dead wood, beetles assemblages, mycophagus beetles, Bolitophagus reticulates, Bitoma crenata 


\section{BEVEZETÉS}

Az elhalt fák közvetlen táplálékforrást jelentenek számtalan rovarfajnak, de közvetve számos további, a szaprotróf gombákat fogyasztó rovar is hasznosithatja őket (Csóka 2014).

A faanyag lebomlására több tényező hat és a lebontást végző fajok összetétele is változatos (Speight 1989). A holtfa mikroélőhelyek összessége, különböző állapotában más-más fajoknak szolgál élőhelyként (Csóka 2000, Ódor et al 2003, Ódor \& Hees 2004). A lebomlási folyamatnak három szakaszát különböztetjük meg. Az egyes szakaszok lefolyásának időtartama, a bennük közreműködő fajok összetétele fafajtól, klimatikus viszonyoktól és mikrohabitat jellemzőktől nagyban függ, ennek megfelelően igen változatos:

1. A kolonizációs szakasz, amely körülbelül két évig tart. Ekkor megjelennek az elsődleges szaproxilofágok, a közvetlenül holtfát fogyasztó fajok, és elkezdik a gombával még nem fertőzött faanyag fogyasztását. Ezzel párhuzamosan a fában megkezdődik a gombák szétterjedése is. A taplók a faanyagot a dekomposztálók számára felvehető formátumúvá alakítják.

2. A dekompozíciós szakaszban a másodlagos szaproxilofág fajok is megjelennek, melyek az elsődleges szaproxilofág fajok működésének termékeit fogyasztják el. A gombák termőtesteit sok másodlagos szaproxilofág faj, föleg taplószúk, álszúk, gyászbogarak fogyasztják. Az egy területen fellelhető taplók menynyisége befolyásolja mind a másodlagos szaproxilofágokat, mind az őket táplálékként elfogyasztó ragadozók, parazitoidok faj- és egyedszámát. Ez a szakasz hozzávetőlegesen 10 évig is eltarthat.

3. A humifikációs szakasz, amikor az elsődleges szaproxilofágok már a tápanyag hiányában eltűnnek, majd a másodlagos szaproxilofágok tápanyag készlete is jelentősen csökken. A harmadlagos szaproxilofágok, azaz a baktériumok és a mikroszkopikus gombák elvégzik a végső lebontást (Csóka 2014, Andrési \& Tuba 2016, Merkl 2016).

A holtfák különböző jellemzői, mint például fafaj, méret, korhadtsági fok, eltérő szaproxilofág gerinctelen fajok megjelenését segítik elő (Csóka \& Lakatos 2014, Merkl 2016). A holtfákon található szaprotróf gombák termőtestei, melyek a faanyag lebontását végzik, nagyon sok mikofág, azaz gombákat fogyasztó gerinctelen fajnak szolgálnak táplálékforrásként és élőhelyként. Ezt a mikofág gerinctelen fajcsoportot sokan az erdők természetességi indikátorának is tekintik (Franc 1997, Gutowski et al 2004).

A kalapos gombák rovarközössége sokkal inkább feltártnak tekinthető hazánkban (Dely-Draskovits 1974), mint a taplógombáké. A taplógombák rovarközösségének vizsgálatával az északi, skandináv országokban többen is foglalkoztak. A téma nehézsége egyrészt abból adódik, hogy a mikológusok és a rovarászok szaktudása ritkán találkozik (Merkl 2016). Magyarországon a kevésbé vizsgált témák közé tartoznak maguk a taplók és a hozzájuk köthető bogárközösség is. Jelen tanulmány egyik célja az eddigi, hazánkban elvégzett, kifejezetten a bükkfataplóhoz (Fomes fomentarius) kötődő bogárközösségek vizsgálatának eredményeit bemutatni. Hazánkban már folytak a mikofág bogárfajokkal kapcsolatos kutatások (Domboróczki 2006, Csóka 2011, Lakatos et al 2014, Andrési 2015, Andrési 2016). Domboróczki (2006) eredményeit összehasonlította skandináviai vizsgálatok eredményeivel is. Megállapította, hogy a domináns fajok abundanciaviszonyai a vizsgált régiók között eltérőek voltak. Feltételezése szerint a különböző klimatikus adottságokból és a vegetáció eltérő fajösszetételéből adódóan a Skandináviában domináns fajokat, hazánkban az ugyanazon nemzetségbe tartozó rokon fajok helyettesíthetik. A külföldi szakirodalmakat tekintve többen is megállapították, hogy a mikofág rovarfajok nem mindegyike polifág, van közöttük specialista, amely csak bizonyos gombafajhoz kötődik (Hackman \& Meinander 1979, Lacy 1984, Hanski 1989).

A taplógombák rovarfaunájának kinevelésére számos különböző módszer létezik, mint például a keltetőedényes csapdák, a kifuttató csapdák, a törzs-ablakcsapdák, a fára akasztott ablakcsapdák, valamint a sátorcsapdák (Domboróczki 2006).

Az összehasonlító vizsgálatunk célja az eddig eredmények összegzése volt, hogy bemutassuk a hazai bükkfataplók bogárközösségét, valamint, hogy meghatározzuk a különböző mennyiségi jellemzőket, mint pél- 
dául a fajok egyedszám és dominancia értékét. Azért a bükkfataplót választottuk vizsgálatunk tárgyának, mert a bogárfaunájával kapcsolatos hazai ismeretek meglehetősen hiányosak, annak ellenére, hogy hazánkban általánosan elterjedt, és a lombos fák leggyakoribb törzskorhasztó taplófaja.

\section{ANYAG ÉS MÓDSZER}

\section{A bükkfatapló rövid bemutatása}

A bükkfatapló (Fomes fomentarius) (1. ábra) a Poliporales rend, Polyporaceae család, Fomes nemzetségébe tartozik. Jellemzően a lombos fák törzskorhasztó taplófaja. Fő tápnövényén, a bükkön (Fagus sylvatica) kívül megtalálható többek között nyíren (Betula pendula), nemesnyárakon (Populus x euramericana), füzeken (Salix sp.), tölgyeken (Quercus sp.) és platánon (Platanus spp.) is. A cellulóz, a hemicellulóz és a lignin lebontásához szükséges enzimekkel is rendelkezik, azaz fehérkorhasztó. Szimultán korhasztónak is nevezik, mert a szénhidrát és a lignin sejtfalalkotókat ugyanazon időben, ugyanolyan mértékben képes bontani. Fakultatív nekrofiton, azaz a fák életmüködést nem folytató szöveteit fogyasztja, de szaprofitonként is képes megélni, így az elpusztult faanyagot hosszabb ideig korhasztja (Igmándy 1991, Szabó 2003). A táplálkozását tekintve a legmagasabb rendű gombákhoz tartozik, ami az jelenti, hogy az erősen gesztesedett, lignifikált faanyagot is képes lebontani, és annak minden alkotórészét fel is tudja használni (Haracsi 1969). A termőtest fás, pata alakú, csöves rétegü, az állaga kemény. Átmérője 5-45 cm, szélessége 3-25 cm, míg a vastagsága 2-25 cm (Haracsi 1969, Phillips 1981, Igmándy 1991). A növekedési zónáknak megfelelően a kalap felülete barázdált (Gerhardt 2008). A pontos beazonosítás céljából a termőtestből vett mintát $\mathrm{KOH} \mathrm{(2-5 \% -0s)-oldatba} \mathrm{helyeztük} \mathrm{és} \mathrm{így} \mathrm{a} \mathrm{szakirodalomnak}$ (Igmándy 1991) megfelelően a termőréteg esetén vérvörös elszíneződést, míg a hús esetén feketedő elszíneződést tapasztaltunk, valamint a hús szöszössé-gyapjassá vált. A spórák, melyek alakja megnyúlt ellipszoid, szórása tavasztól nyár elejéig történik. Évelő, nem ehető taplógomba (Haracsi 1969, Phillips 1981, Igmándy 1991). Erdészeti szempontból a legveszélyesebb parazita gombákhoz tartozik. Magyarországon komoly gondot okoz az erős revesítő, azaz korhasztó képességével. Hazánkban a kultúr akácosok kivételével mindenütt megtalálható. A fákat sebzéseken, ágcsonkokon keresztül képes fertőzni. Korábban úgy vélték, hogy az ellene való védekezésnél a sebzések elkerülése és a fertőzött törzsek állományból való eltávolítása fontos (Szabó 2003).
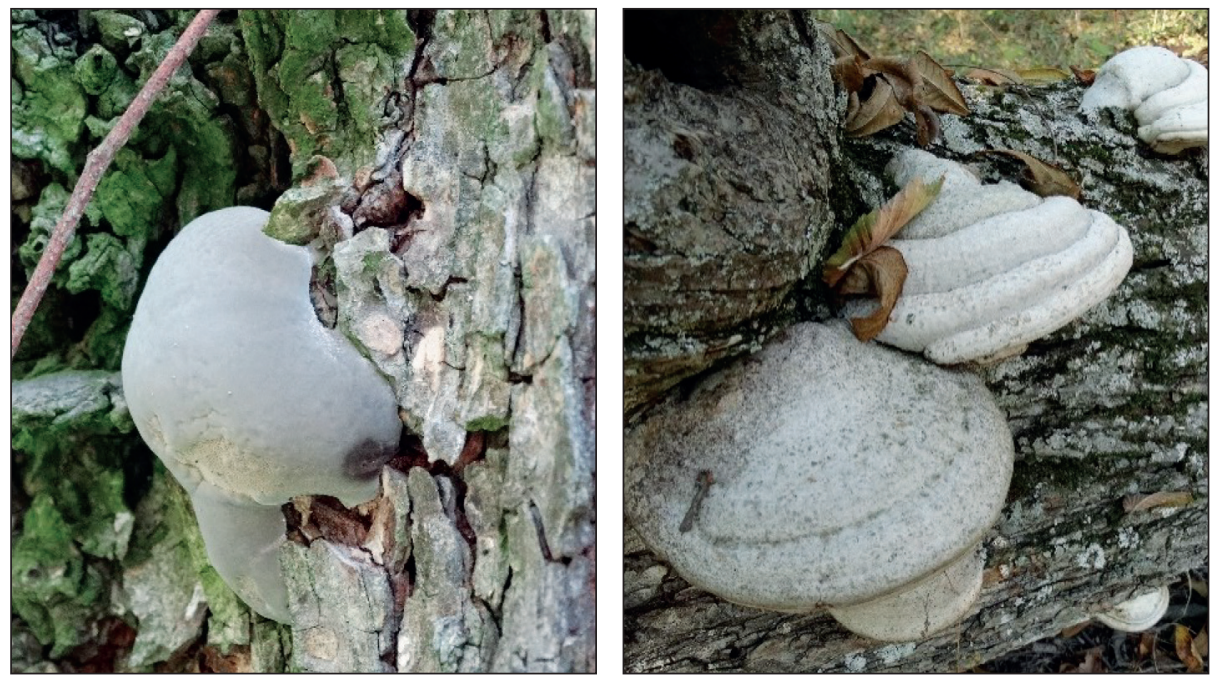

1. ábra: Egyéves (balra) és többéves (jobbra) Fomes fomentarius termőtestek

Figure 1: One-year (left) and several-year (right) fruiting bodies of Fomes fomentarius 


\section{A terepi gyüjtés, kinevelés, határozás bemutatása}

A termötestek gyüjtése 2010. szeptember 1. és 2013. május 8. között véletlenszerủen történt. A bükkfataplók 27 magyarországi településhez tartozó 35 különböző erdőtagból származnak (2. ábra) jellemzően bükkröl (Fagus sylvatica L.) és kocsánytalan tölgyröl (Quercus petraea (Matt.) Liebl.).

A jelzett időszakban összesen 193 termőtest került begyüjtésre, melyek között volt egyéves és több éves is. A taplógombák egy részét a NAIK ERTI Erdővédelmi Osztályának munkatársai gyüjtötték 2010-től 2013-ig, és a bogarak nevelése is ott történt, míg a másik részt a Soproni Egyetem Erdővédelem Intézetének munkatársai gyüjtötték 2013-ban és ezekből a mintákból a bogarak kinevelésére az Intézet rovarkeltetőjében került sor.

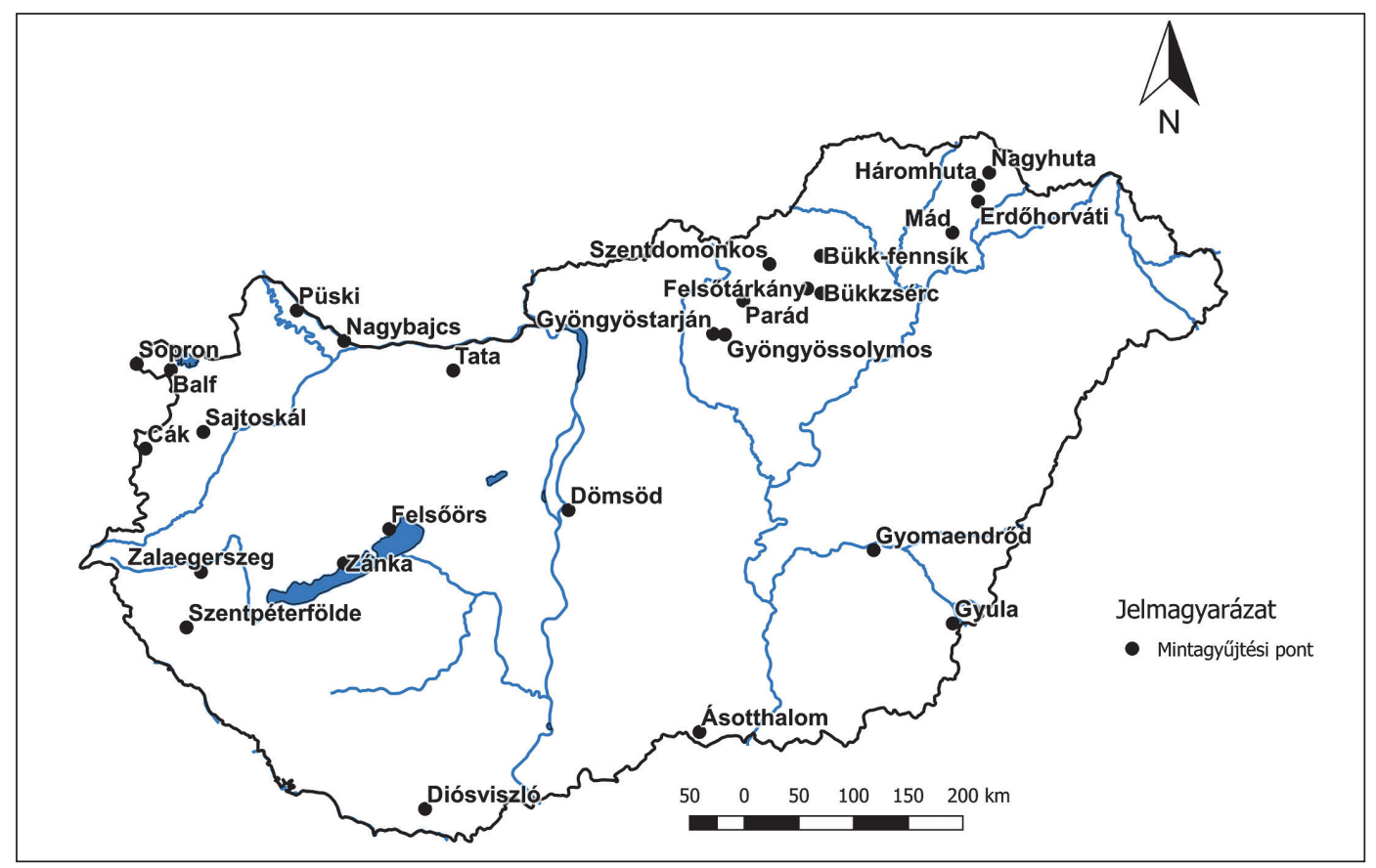

2. ábra: A Fomes fomentarius termőtestek gyüjtési helyei

Figure 2: The sampling site's in Hungary

A minták faanyagtól történő elválasztásánál arra figyeltünk, hogy lehetöleg az ép, kirepülési nyílásokat még nem tartalmazó, taplógombák kerüljenek begyüjtésre, amelyeket a faanyaghoz minél közelebb választottunk el, kerülve a kéreghez kötődő rovarközösség begyüjtését. A taplógombákat a leszedést követően megtisztítatlanul helyeztük el a keltetőedényekbe. Ezzel a termőtestek rovarközösségének komplexitását akartuk megőrizni. A gyűjités során feljegyeztük a gyüjtés helyét, idejét, a tápnövényt, és annak minőségét (álló, vagy fekvő holtfa, tuskó).

A két módszertan különbségei miatt jelen publikáció célja csak a bükkfataplókhoz kötődő bogárfajok diverzitásának bemutatása. Vizsgálataink során minden esetben keltetőedényes nevelést végeztünk. Ennek lényege, hogy a rovarok, melyek pozitív fototaxissal rendelkeznek a sötét keltetőedényböl a fény felé mozognak, így viszonylag egyszerüen kiemelhetők a keltetőedényekből. A Sopronban gondozott taplógombákat papírzacskókban helyeztük el, a mintákat laboratóriumi körülmények között tároltuk, a Soproni Egyetem Erdöművelési és Erdővédelmi Intézet rovarkeltetőjében, $20 \pm 1^{\circ} \mathrm{C}$-on és $60 \%$-os páratartalom mellett, ahol $16: 8$ volt a megvilágított és a sötét órák aránya. A Sopronban tárolt minták nevelő zacskóinak üritése 6 hetente történt. 
A termőtestek az ERTI Mátrafüredi Kísérleti Állomásán terepi hőmérséklettel megegyező körülmények között a szabadban lévő fedett tárolóban kerültek elhelyezésre. Itt a bogarakat két hetes ciklusokban gyüjtötték be a tárolóedényekből. Közvetlen napfény egyik esetben sem érte a keltetőedényeket. A kinevelt rovarokat határozásig mélyhütőben tároltuk. A határozásnál a kérdéses fajok esetén specialistához fordultunk.

Mindkét mintavételezési módszer sikeresnek bizonyult, de a minták tárolásából és a különböző ürítési időközökből származó eltérések miatt a kinevelt bogárfajok faunisztikai vizsgálatán kívül más összehasonlító vizsgálat elvégzése nem volt szakmailag indokolt és kivitelezhető. A továbbiakban a mintavételezés módszertanában változtatásokat, egységesítéseket szükséges végrehajtanunk a bővebb összehasonlító vizsgálatok elvégzésének céljából.

\section{EREDMÉNYEK ÉS MEGVITATÁSUK}

A három év alatt begyüjtött 193 Fomes fomentarius termőtest 91,7\%-ából, azaz 177 termőtestből sikerült rovarokat kinevelni, míg 8,3\%-ából, azaz 16 termőtestből nem kelt ki egyetlen rovarfaj sem. A bogarak (Coleoptera) rendjéből összesen 14 család 36 fajának 4726 egyedét neveltük ki. Ebből pontos, faji szintü meghatározásra 9 család 27 fajának 4703 egyede került. Egyes fajokat csak család (Corylophidae) vagy alcsalád (Scolytinae) szinten, míg másokat csak nemzetség szinten sikerült meghatározni, pl.: Cryptophagus sp., Epuraea sp., Ptinus sp., Sepedophilus sp.

Ahogy az 1. táblázatban látható, a legtöbb faj (9) a Ciidae családból került ki. Egyedszámok tekintetében szintén a Ciidae család kiemelkedő, 3186 egyeddel. Legnagyobb egyedszámmal (1753 db) az utóbbi család Rhopalodontus perforatus faja képviseltette magát. Ezt a fajt 17 településről származó mintából sikerült kinevelnünk. A második leggyakoribb család a Tenebrionidae család 941 egyeddel, míg a harmadik az Anobidae család 546 egyeddel. A Cerylonidae, az Erotylidae, a Histeridae, a Monotomidae, a Mycetophagidae és a Zopheridae családokból 15-nél kevesebb egyedet sikerült kinevelnünk. A R. perforatus mellett nagy egyedszámban volt még jelen a Tenebrionidae családba tartozó Bolitophagus reticulatus is (898 példány), amelyet 14 településről származó termőtestből határoztunk meg. Ez a faj jellemzően Fomes fomentariushoz kötődik (Hůrka 2005). Egy másik gyászbogárfaj, a Neomida haemorrhoidalis is jellemzően a bükkfataplóban él (3. ábra). Mindkét faj rágása igen feltünő (Reibnitz 2006, Merkl 2016). A taplószúfélék (Ciidae) családjába tartozó $R$. perforatus a bükkfataplón és annak közeli rokonain kívül más taplókban nem telepszik meg (Merkl \& Vig 2011). Ebben a gombafajban él még a Cis-fajok közül a C. jacquemartii és a C. castaneus is (Merkl 2016). Az általunk kinevelt fajok között nagy mennyiségben határoztuk meg a $C$. castaneust, míg a $C$. jacquemartii lényegesen kisebb arányban fordult elö. Az álszúfélékhez tartozó Dorcatoma dresdensis, a $D$. robusta és a D. minor is nagy számban elöfordulhatnak a F. fomentarius termőtestekben. Ezen fajok mindegyikét sikerült a mintáinkban is beazonositani.

1. táblázat: A bükkfataplókból kinevelt bogárfajok, egyedszámuk és családba történő besorolásuk

Table 1: Beetle species reared from tinder conk, the number of individuals per family

\begin{tabular}{|c|c|c|c|}
\hline Fajnév & Egyedszám (db) & $\sum_{(\mathrm{db})}$ & Család \\
\hline Dorcatoma dresdensis Herbst, 1792 & 171 & \multirow{4}{*}{546} & \multirow{4}{*}{ Anobiidae } \\
\hline Dorcatoma minor Zahradník, 1993 & 137 & & \\
\hline Dorcatoma robusta Strand, 1938 & 237 & & \\
\hline Ptinus sexpunctatus Panzer, 1789 & 1 & & \\
\hline Cerylon histeroides (Fabricius, 1792) & 2 & 2 & Cerylonidae \\
\hline
\end{tabular}


Az 1. táblázat (folytatás)

Table 1 (cont.)

\begin{tabular}{|c|c|c|c|}
\hline Fajnév & Egyedszám (db) & $\sum_{(\mathrm{db})}$ & Család \\
\hline Cis boleti (Scopoli, 1763) & 118 & \multirow{9}{*}{3186} & \multirow{9}{*}{ Ciidae } \\
\hline Cis castaneus (Herbst, 1793) & 669 & & \\
\hline Cis jacquemartii Mellié, 1848 & 144 & & \\
\hline Cis micans (Fabricius, 1792) & 9 & & \\
\hline Ennearthron cornutum (Gyllenhal, 1827) & 1 & & \\
\hline Octotemnus glabriculus (Gyllenhal, 1827) & 486 & & \\
\hline Rhopalodontus perforatus (Panzer, 1809) & 1753 & & \\
\hline Sulcacis affinis (Gyllenhal 1827) & 1 & & \\
\hline Sulcacis fronticornis (Panzer, 1809) & 5 & & \\
\hline Dacne bipustulata (Thunberg 1781) & 5 & 5 & Erotylidae \\
\hline Dendrophilus punctatus (Herbst, 1792) & 1 & 1 & Histeridae \\
\hline Rhizophagus dispar (Paykull, 1800) & 2 & 2 & Monotomidae \\
\hline Litargus connexus (Geoffroy 1785) & 3 & \multirow{4}{*}{6} & \multirow{4}{*}{ Mycetophagidae } \\
\hline Mycetophagus decempunctatus Fabricius 1801 & 1 & & \\
\hline Mycetophagus piceus Fabricius, 1792 & 1 & & \\
\hline Mycetophagus quadripustulatus (Linnaeus 1761) & 1 & & \\
\hline Bolitophagus reticulatus (Linnaeus, 1767) & 898 & \multirow{5}{*}{941} & \multirow{5}{*}{ Tenebrionidae } \\
\hline Hypophloeus unicolor Piller et Mitterpacher, 1783 & 1 & & \\
\hline Eledonoprius armatus (Panzer, 1799) & 1 & & \\
\hline Neomida haemorrhoidalis (Fabricius, 1787) & 39 & & \\
\hline Pentaphyllus testaceus (Hellwig 1792) & 2 & & \\
\hline Bitoma crenata (Fabricius 1775) & 14 & 14 & Zopheridae \\
\hline$\Sigma$ & 4703 & & \\
\hline
\end{tabular}
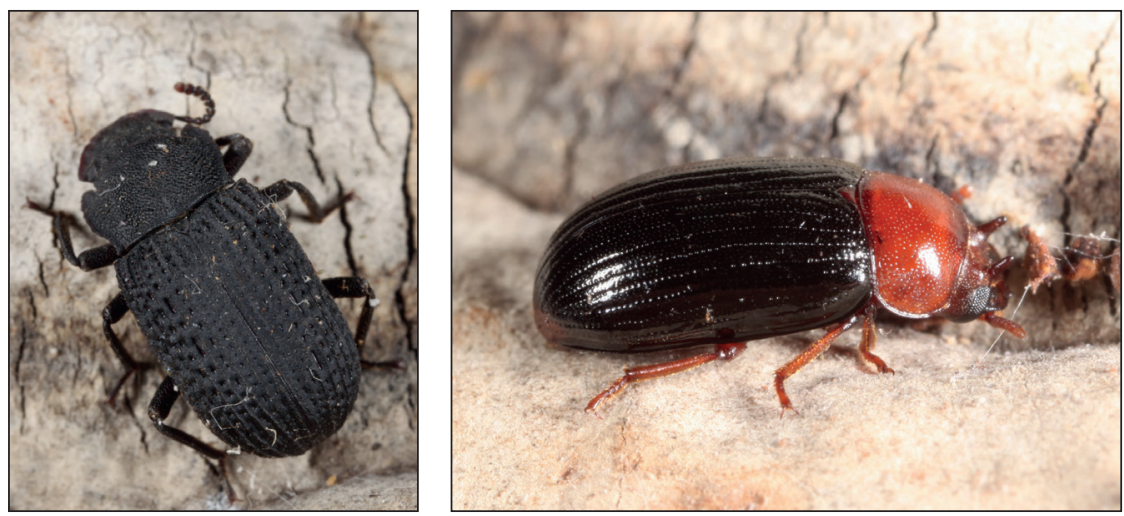

3. ábra: Tipikusan bükkfataplóhoz kötődő fajok, a Bolitophagus reticulatus és a Neomida haemorrhoidalis (Fotók: Csóka György) Figure 3: Bolitophagus reticulatus and Neomida haemorrhoidalis, typically associated with F. fomentarius (Photo: György Csóka) 
A kinevelt bogarak különböző élőhelytípusokhoz kötődnek. Szakirodalmi adatok alapján ezt mutatja be a 2. táblázat. A meghatározott bogárfajok nem mindegyike kötődik közvetlenül a termőtesthez, hiszen találtunk a taplógombában és kéreg alatt egyaránt élő fajokat (pl.: Mycetophagidae család fajai); taplóban, kéreg alatt és ragadozó életmódot folytató rovarokat (pl.: Rhizophagus dispar); ragadozó fajokat (pl.: Bitoma crenata); valamint kéreg alatt előforduló fajokat (pl.: Hypophloeus unicolor) és a fákhoz kötődő fajokat is (pl.: Ptinus sexpunctatus). A beazonosított fajok 63\%-a közvetlenül taplógombákhoz kötődik, mint pl. a Ciidae család fajai (4. ábra). A ragadozó életmódot folytató fajokat (Dendrophilus punctatus, $B$. crenata) feltehetően más rovarfajok vonzották a taplógombához, és így kerültek a termőtestekkel begyüijtésre.

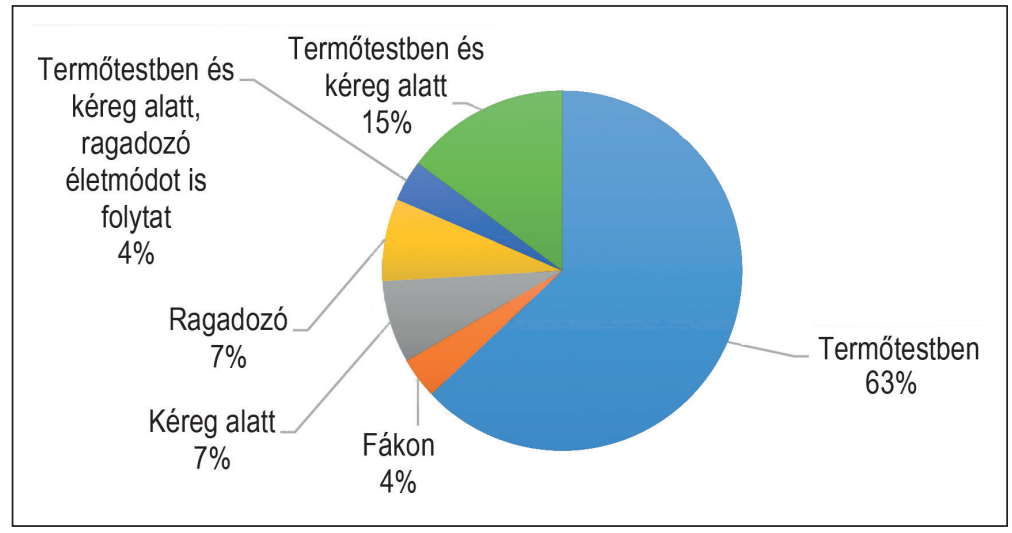

4. ábra: A meghatározott rovarok mikrohabitat szerinti előfordulása

Figure 4: Occurrence of insects according to microhabitat

2. táblázat: $A$ kinevelt bogárfajok élőhelye és életmódja szakirodalmi források alapján

Table 2: The habitat and biology of the reared beetle species based on the literature

\begin{tabular}{|c|c|c|c|}
\hline Családnév & Fajnév & Élöhely, amihez kötődik & Forrás \\
\hline \multirow{4}{*}{ Anobiidae } & D. dresdensis & \multirow{3}{*}{ Termőtestben } & Merkl \& Vig 2011 \\
\hline & D. minor & & Merkl \& Vig 2011 \\
\hline & D. robusta & & Hůrka 2005 \\
\hline & P. sexpunctatus & Fákon & Merkl \& Vig 2011 \\
\hline Cerylonidae & C. histeroides & Kéreg alatt & Merkl \& Vig 2011 \\
\hline \multirow{9}{*}{ Ciidae } & C. boleti & \multirow{9}{*}{ Termőtestben } & Hůrka 2005 \\
\hline & C. castaneus & & Tóth 1999 \\
\hline & C. jacquemartii & & Harde, Severa \& Möhn 2000 \\
\hline & C. micans & & Harde, Severa \& Möhn 2000 \\
\hline & E. cornutum & & Tóth 1999 \\
\hline & O.glabriculus & & Hůrka 2005 \\
\hline & R. perforatus & & Jelinek \& Audisio 2013 \\
\hline & S. affinis & & Hůrka 2005 \\
\hline & S. fronticornis & & Lompe 2010 \\
\hline Erotylidae & D. bipustulata & Termőtestben & Pendleton \& Pendleton 2014 \\
\hline
\end{tabular}


A 2. táblázat (folytatás)

Table 2 (cont.)

\begin{tabular}{|c|c|c|c|}
\hline Családnév & Fajnév & Élöhely, amihez kötődik & Forrás \\
\hline Histeridae & D. punctatus & Odvas fákban ragadozó & Merkl 2016 \\
\hline Monotomidae & R. dispar & $\begin{array}{l}\text { Termőtestben és kéreg alatt, ragadozó } \\
\text { életmódot is folytat }\end{array}$ & Hůrka 2005 \\
\hline \multirow{4}{*}{ Mycetophagidae } & L. connexus & \multirow{4}{*}{ Termőtestben és kéreg alatt } & Pendleton and Pendleton 2014 \\
\hline & M. decempunctatus & & Tóth 1999 \\
\hline & M. piceus & & Tóth 1999 \\
\hline & M. quadripustulatus & & Hůrka 2005 \\
\hline \multirow{5}{*}{ Tenebrionidae } & H. unicolor & Kéreg alatt & Szontagh 1999 \\
\hline & B. reticulatus & \multirow{4}{*}{ Taplóban } & Hůrka 2005 \\
\hline & E. armatus & & Merkl \& Vig 2011 \\
\hline & N. haemorrhoidalis & & Reibnitz 2006 \\
\hline & P. testaceus & & Lundberg 1997 \\
\hline Zopheridae & B. crenata & Kéreg alatti ragadozó & Hůrka 2005 \\
\hline
\end{tabular}

A 3. táblázatban mutatjuk be az egyes gyüjtési helyekhez tartozó bogárfajok egyedszámát, zárójelben pedig, hogy mennyi termőtestből származik az adott egyedszám. A leggyakoribb faj, a $R$. perforatus volt. Legtöbb egyedét a Szentpéterföldéröl és Diósviszlóról származó termőtestekböl neveltük ki. Érdekes, hogy ahol a $R$. perforatus fordult elö kiemelkedő számban, ott lényegesen kevesebb $B$. reticulatus fordult elő (Szentpéterfölde), míg ahol a $B$. reticulatus nagyobb egyedszámú megjelenése volt jellemző, ott alig találtunk $R$. perforatust (Felsőtárkány). Egy-egy egyedet sikerült a következő fajokból meghatározni: Ptinus sexpunctatus (Szentpéterfölde), Ennearthron cornutum (Gyöngyössolymos), Sulcacis affinis (Sopron), Dendrophilus punctatus (Gyöngyössolymos), Mycetophagus decempunctatus (Zalaegerszeg), M. piceus (Nagyhuta), M. quadripustulatus (Zalaegerszeg), Eledonoprius armatus (Nagyhuta), Hypophloeus unicolor (Bükk-fennsík).

\section{KÖVETKEZTETÉSEK}

A vizsgálatunk célja a hazánkban gyakori bükkfatapló hazai bogárközösségének áttekintése volt. Az eredményeinket tekintve gazdag bogárközösségről van szó, hiszen a 177 Fomes fomentarius termőtestből 27 bogárfaj került meghatározásra, míg 16 termőtestböl egyetlen egy fajt sem tudtunk kinevelni. Fontos hangsúlyozni, hogy a kinevelt bogárfajok többségében a taplókhoz szorosan kötődő specialista fajok, de kisebb részt elöfordultak a fákon, kéreg alatt élők és ragadozók is. Többük kizárólag egy-egy taplófajhoz társitható, így például a meghatározott fajok között találtunk tipikusan bükkfataplóhoz kötődő fajt (Neomida haemorrhoidalis), de a szakirodalom által F. fomentariushoz kötődő Cis glabratust (Merkl \& Vig 2011) nem sikerült kinevelnünk. A leggyakoribb faj a Ciidae családba tartozó Rhopalodontus perforatus volt, amelyet 17 településről gyüjtött taplógomba esetén sikerült beazonosítani. A második legnagyobb egyedszámú fajt, a Bolitophagus reticulatust 14 településről származó termőtestből határoztuk meg. A Cerylonidae, Erotylidae, Histeridae, Monotomidae, Mycetophagidae és Zopheridae családok fajait 15 alatti egyedszámokkal sikerült meghatároznunk. 


\begin{tabular}{|c|c|c|c|c|c|c|c|c|c|c|c|c|c|}
\hline еұеиәл ' & & & & & & & $-E$ & & & & $m=$ & & \\
\hline snəכełsət d & & & & & & & & & & & $\sim \equiv$ & & \\
\hline s!|ер!очдошәец 'N & & & & & & & & $\stackrel{ }{2} \equiv$ & & & & $+E$ & \\
\hline solos!un $\mathrm{H}$ & & & $-E$ & & & & & & & & & & \\
\hline sпғешие ' $\exists$ & & & & & & & & & & & & & \\
\hline sпłеןпю!әд 'g & & & & เ & & & & $\bar{\sim} \sqrt{0}$ & & 잉 & & 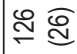 & \\
\hline snıe|mısndupenb ' $W$ & & & & & & & & & & & & & \\
\hline snəכ!d ' $W$ & & & & & & & & & & & & & \\
\hline sпџејоundшәэәр ' $W$ & & & & & & & & & & & & & \\
\hline sпхәииол 7 & & & & & & & & & & & & & \\
\hline seds!p 'y & & & $-E$ & & & & & & & & & & $-E$ \\
\hline sniełound ' 0 & & & & & & & & & & & & $-€$ & \\
\hline ełejmısnd!q '0 & $-E$ & & & & & & & & & & & & \\
\hline s! & & & & & & & & & & & & & \\
\hline s!ulye 's & & & & & & & & & & & & & \\
\hline sпједондd 'y & & & & $\mp \Theta$ & & $\frac{\tilde{y}}{\dot{y}}$ & 隹 $=$ & $\stackrel{\sim}{\infty}$ & & $\bar{\sim} \sqrt{a}$ & $\bar{\infty}$ & 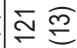 & $0 \cong$ \\
\hline snןnэuqge|b 0 & & $-E$ & & & $\underset{m}{\hat{m}}$ & $\because \approx$ & $m=$ & & $-E$ & & & $\stackrel{2}{2}$ & \\
\hline шпұпиого : $\exists$ & & & & & & & & & & & & $-E$ & \\
\hline sues!m '0 & & & & & & & $-E$ & & & & & $\sim €$ & \\
\hline !нешәпьэе! '0 & & & & & & & & & & প্ল & & ฮ & \\
\hline snәuеłses '0 & $-E$ & & & & $\sim \mathbb{I}$ & & & & & 割 8 & & 咅包 & 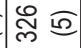 \\
\hline$! \ni / 0 q$ '0 & & & & & $-\cong$ & & & & & $\sim \widehat{\mathbb{a}}$ & & 20 & $-E$ \\
\hline sәр!одәાs! '0 & & & & & & & & & & & & $-E$ & \\
\hline snłęoundxəs dd & & & & & & & & & & & & & \\
\hline ełsnqos 'O & & & & & & & & & & & & 迨 & \\
\hline лои!ш '0 & & & & $\approx \widetilde{m} \equiv$ & & & & 응 & & 㶽王 & & $\sim \mathbb{\Xi}$ & \\
\hline sısuәpsәлp '0 & & & & & & & & & & & & & $?$ \\
\hline & 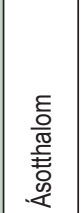 & 皆 & 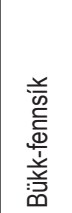 & 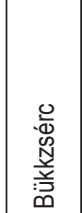 & 离 & 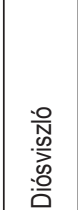 & 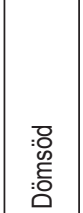 & 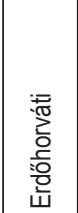 & 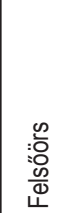 & 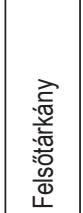 & 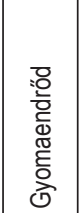 & 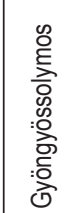 & 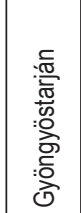 \\
\hline
\end{tabular}




\begin{tabular}{|c|c|c|c|c|c|c|c|c|c|c|c|c|c|}
\hline ејеиәл ' & & & & & & & & & & & & & \\
\hline snәכełsət d & & & & & & & & & & & & & \\
\hline s!!ер!очцошәеч 'N & & & & & & $-E$ & & $-E$ & & & $\infty \mathbb{E}$ & & \\
\hline solos!lun $\mathrm{H}$ & & & & & & & & & & & & & \\
\hline sпџешие ' $\exists$ & & & & & $-E$ & & & & & & & & \\
\hline 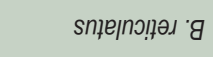 & & $\forall$ ल & $-\widehat{E}$ & & & $\pm \sqrt{2}$ & 을 & $+E$ & के & 屃 & $\stackrel{乛}{\Xi}$ & 으 조 & $\varphi \equiv$ \\
\hline snıe|mısndupenb 'W & & & & & & & & & & & & $-E$ & \\
\hline snəo!d ' $W$ & & & & & $-E$ & & & & & & & & \\
\hline sпџејэundшәэәр 'W & & & & & & & & & & & & $-E$ & \\
\hline snхәииол 7 & & & & & & & & & & & & $m \mathbb{I}$ & \\
\hline ıeds!p 'y & & & & & & & & & & & & & \\
\hline snjełound ' 0 & & & & & & & & & & & & & \\
\hline ełejmındı́ & & & & & & & & $+\widehat{\Xi}$ & & & & & \\
\hline s!uoo!nuouf 'S & & & & & & $n E$ & & & & & & & \\
\hline s!unge 's & & & & & & & & & $-E$ & & & & \\
\hline sпіедодәд 'y & $\stackrel{\sim}{\sim}$ & & $\nabla E$ & $-E$ & & fo & $\sim E$ & & & $-E$ & $\frac{\pi}{\pi}$ & 읕 & $\sim E$ \\
\hline sninọqqe 6 & & & & $\overline{5} \equiv$ & & & & $-E$ & $m \equiv$ & & & is & \\
\hline шпџnшог ' $\exists$ & & & & & & & & & & & & & \\
\hline sueग!l '0 & & & & & & $-E$ & & & & & & $10 \Xi$ & \\
\hline !дешәпьэе! '0 & $-E$ & & & & & $\sim \cong$ & & & & & & & \\
\hline snәuетses '0 & $\approx \widetilde{\Xi}$ & & & & & के & $-E$ & & $+\widehat{\Xi}$ & & & $-E$ & \\
\hline$! \ni / 0 q: 0$ & & & & & & & & & & & $-E$ & 을 & \\
\hline sәр!0-әə઼ડ! '0 & $-E$ & & & & & & & & & & & & \\
\hline snłełoundxəs d d & & & & & & & & & & & $-E$ & & \\
\hline elsnqod 'O & & & & & & & & & & & & $\approx \equiv$ & \\
\hline лои!ш '0 & & & & & & 웅 & & & & & & & \\
\hline s!suәрsәлp '0 & $-E$ & & & & & & & & & & & & \\
\hline & $\frac{\pi}{5}$ & 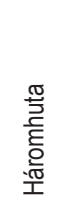 & $\sum_{i}^{\infty}$ & $\begin{array}{l}\frac{\mathscr{3}}{\pi} \\
\frac{0}{\pi} \\
\frac{\pi}{2}\end{array}$ & 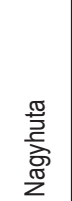 & 票 & 旁 & 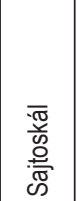 & $\begin{array}{l}\text { 음 } \\
\text { के }\end{array}$ & 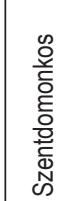 & 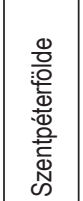 & 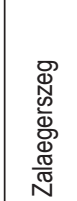 & $\underset{\substack{\mathbb{N} \\
\mathbb{N}}}{\mathbb{N}}$ \\
\hline
\end{tabular}


A téma napjainkban egyre nagyobb jelentőséggel bír, hiszen egyre nagyobb szerepet kap az erdőkben a holtfa mennyiségének növelése. A továbbiakban más taplófajok bogárközösségét is vizsgáljuk, valamint a mintagyüjtésnél az adatállományt folyamatosan bővítjük. Jelen tanulmányban a bükkfataplók faunisztikai vizsgálata került bemutatásra. A különböző területekről, fafajokról származó bükkfataplók bogárközössége eltérést mutat, így ezt a kísérletet a továbbiakban egységes mintavételezéssel is célszerủ megvizsgálni. Érdemes lenne a taplógomba és a hozzájuk kötődő bogárközösség rendszerében a parazitoidok vizsgálata, hiszen (Komonen 2001) is utal a nagyszámú jelenlétükre.

\section{KÖSZÖNETNYILVÁNÍTÁS}

A határozás során a kérdéses bogárfajokkal Dr. Merkl Ottóhoz fordultunk. Ezúton is köszönjük a segítségét.

A kutatás a TÁMOP-4.2.2.A-11/1/KONV-2012-0004, 'Silva naturalis A folyamatos erdőborítás megvalósitásának ökológiai, konzervációbiológiai, közjóléti és természetvédelmi szempontú vizsgálata’ keretén belül valósult meg.

\section{FELHASZNÁLT IRODALOM}

Andrési R. 2015: Taplógombák rovarközösségének vizsgálata. Diplomamunka. NYME EMK. Sopron, 75.

Andrési R. 2016: Bükktapló (Fomes fomentarius L.) rovarközösségének éven belüli változása. Szakdolgozat. NYME EMK. Sopron, 61.

Andrési R. \& Tuba K. 2016: Diversity of beetle communities in tinder fungus (Fomes fomentarius). In: Ács K., Bencze N., Bódog F., Haffner T., Hegyi D., Horváth O. M. \& et al. (eds): V. Interdiszciplináris Doktorandusz Konferencia Konferenciakötet. Pécs, 4-12.

Csóka Gy. 2000: Az elpusztult, korhadó fa szerepe az erdei biodiverzitás fenntartásában. In: Frank T. (ed): Természeterdő-gazdálkodás. MME és Pro Silva Hungária Egyesület, Eger, 85-96.

Csóka Gy. 2011: A holtfa erdő- és természetvédelmi szerepe magyarországi keménylombos erdőkben. Az OTKA K68618 sz. pályázat zárójelentése. Erdészeti Tudományos Intézet, Mátrafüred, 13.

Csóka Gy. 2014: Holtfa, mint életfeltétel. In: Csóka Gy. \& Lakatos F. (eds): Silva naturalis - A holtfa. Vol. 5. Sopron, 45-48.

Csóka Gy. \& Lakatos F. 2014: Az erdei holtfa megjelenési formái. In: Csóka Gy. \& Lakatos F. (eds): Silva naturalis - A holtfa. Vol. 5. Sopron, 29-36.

Dely-Draskovits Á. 1974: Systematische und ökologische Untersuchung an der in Ungarnals Schädlinge der Hutpilze auftretenden Fliegen VI. Mycetophilidae (Diptera). Folia Entomologica Hungarica 27: 29-41.

Domboróczki G. 2006: Taplógombákon élő rovarfauna vizsgálata. Diplomaterv, Nyugat-Magyarországi Egyetem. Sopron, 51.

Franc V. 1997: Mycetophilous beetles (Coleoptera mycetophila) - indicators of well preserved ecosystems. - Biologia, (Bratislava) 52 (2): 181-186.

Gerhardt E. 2008: Gombászok kézikönyve. M-érték Kiadó Kft., Pozkal-Inowroclaw.

Gutowski J. M., Bobiec A., Pawlaczyk P. \& Zub K. 2004: The afterlife of a tree. WWF Polska. Warszawa-Hajnówka.

Hackman W. \& Meinander M. 1979: Diptera feeding as larvae on macrofungi in Finland. Annales Zoologici Fennici 16: $50-83$.

Hanski I. 1989: Fungivory: fungi, insects and ecology. In: Wilding N., Collins N.M., Hammond P.M. \& Webber J.F. (eds): Insect-fungus interactions. Academic Press, London, 25-68. DOI: 10.1016/b978-0-12-751800-8.50008-2

Haracsi L. 1969: Erdészeti Növénykórtan. Akadémiai Kiadó, Budapest, 316.

Harde K. W., Severa F. \& Möhn E. 2000: Der Kosmos Käferführer. Franckh- Kosmos Verlags- GmbH \& Co., Stuttgart. 352 pp. Hůrka K. 2005: Beetles of the Czech and Slovak Republics. Nalkadatelství KABOUREK, Czech Republic, 390.

Igmándy Z. 1991: A magyar erdők taplógombái. Akadémiai Kiadó, Budapest, 112.

Komonen A. 2001: Structure of insect communities inhabiting old-growth forest specialist bracket fungi - Ecological Entomology 26: 63-75. DOI: 10.1046/j.1365-2311.2001.00295.x 
Lacy R. C. 1984: Predictability, toxicity, and trophic niche breadth in fungus-feeding Drosophilidae (Diptera). Ecological Entomology, 9: 43-54. DOI: 10.1111/j.1365-2311.1984.tb00697.x

Lakatos F., Tuba K., Szabó I., Varga Sz., Sipos Gy., Molnár M. \& et al 2014: A holtfa szerepe a diverzitás fenntartásában. - In: Bartha D. \& Puskás L. (eds): Silva naturalis Vol. 6. - A folyamatos erdőboritás megvalósitásának ökológiai, konzervációbiológiai, közjóléti és természetvédelmi szempontú vizsgálata. Nyugat-magyarországi Egyetem Kiadó, Sopron, 148-164.

Merkl O. \& Vig K. 2011: Bogarak a Pannon Régióban. Vas Megyei Múzeumok Igazgatósága, B. K. L. Kiadó és a Magyar Természettudományi Múzeum, Szombathely, 494.

Merkl O. 2016: A szaproxilofág bogarak (Coleoptera) szerepe a holtfa lebontásában. In: Korda M. (ed): Az erdőgazdálkodás hatása az erdők biológiai sokféleségére. [XXXXX]. Tanulmánygyűjitemény. Duna-Ipoly Nemzeti Park Igazgatóság, Budapest, 129-154.

Ódor P., Heilmann-Clausen J., Christensen M., Aude, E., van Dort K.W., Piltaver A. \& et al. 2003: Diversity of dead wood inhabiting fungi and bryophytes in semi-natural beech forests in Europe. Nat-Man Working Report 32. DOI: 10.1016/j. biocon.2006.02.004

Ódor P. \& van Hees A.F.M. 2004: Preferences of dead wood inhabiting bryophytes for decay stage, log size and habitat types in Hungarian beech forests. Journal of Bryology 26: 79-95. DOI: 10.1179/037366804225021038

Phillips R. 1981: Mushrooms and other fungi of Great Britain \& Europe. New Interlitho S.p.A., Milan, 228.

Szabó I. 2003: Erdei fák betegségei, Erdészeti növénykórtan. Szaktudás Kiadó Ház, Budapest, 179.

Szontagh P. 1999: Osztag: Heteromera - Felemás lábfejizes bogarak, Család: Tenebrionidae - Gyászbogarak. In: Tóth J. (ed): Erdészeti rovartan. Agroinform Kiadó, Budapest, 226-228.

Tóth J. 1999: Osztag: Diversicornia - Különböző csápú bogarak, Család: Mycetophagidae - Gombabogarak. In: Tóth J. (ed): Erdészeti rovartan. Agroinform Kiadó, Budapest, 219.

\section{Internetes hivatkozások}

Jelinek J. \& Audisio A. 2013: https://fauna-eu.org/cdm_dataportal/taxon/9d9eafdb-6304-460b-8b69-556090714a5b (2018. február)

Lompe A. 2010: Die Käfer Europas, http://www.coleo-net.de/coleo/texte/sulcacis.htm (2018. február)

Lundberg S. 1997: Pentaphyllus testaceus, http://artfakta.artdatabanken.se/taxon/101525 (2018. február)

Pendleton T. \& Pendleton D. 2014: The website dedicated to Nottinghamshire's invertebrate fauna, http://www.eakringbirds. com/eakringbirds4/insectinfocusdacnebipustulata.htm (2018. február)

Reibnitz J. 2006: Die Käfer- Fauna Südwestdeutschlands- ARGE SWD Koleopterologen, http://entomologie-stuttgart.de/ ask/node/777\&menu=ste\&mode=ste (2018. február)

2017. évi LVI. törvény az erdőröl, az erdő védelméröl és az erdőgazdálkodásról szóló 2009. évi XXXVII. törvény és egyéb kapcsolódó törvények módosításáról (https://net.jogtar.hu/j/gen/hjegy_doc.cgi?docid=A1700056.TV\&timeshift=fffffff4 \&txtreferer=00000001.TXT\#Ibj0idd1e8) (2018. február)

Érkezett: 2018. április 17.

Közlésre elfogadva: 2018. augusztus 31. 